\title{
ANALISIS PENGELUARAN TRANSPORTASI RUMAH TANGGA (TRANSPORTATION EXPENDITURE) DI KOTA BANDA ACEH
}

\author{
Fuadh Ramadhan $^{1)}$, Sugiarto Sugiarto ${ }^{2)}$, Muhammad Isya ${ }^{3)}$ \\ ${ }^{1)}$ Magister Teknik Sipil, Jurusan Teknik Sipil, Universitas Syiah Kuala \\ ${ }^{2,3)}$ Jurusan Teknik Sipil, Universitas Syiah Kuala \\ Corresponding email: sugiarto@unsyiah.ac.id
}

DOI: http://dx.doi.org/10.29103/tj.v9i2.190

(Received: Maret 2019 / Revised: June 2019 / Accepted: July 2019)

\begin{abstract}
Abstrak
Hingga saat ini, kota Banda Aceh terus mengalami perkembangan pesat baik dalam infrastruktur transportasi maupun peningkatan populasi. Sebagai akibatnya, hal ini mempengaruhi jumlah orang yang melakukan perjalanan untuk kegiatan rutin mereka. Dengan menghabiskan lebih banyak waktu untuk bepergian memiliki pengaruh signifikan terhadap biaya transportasi rutin mereka. Oleh karena itu penelitian ini bertujuan untuk mengetahui model pengeluaran transportasi di Banda Aceh. Model yang dikembangkan dapat digunakan untuk mengeksplorasi karakteristik pengeluaran perjalanan dengan mengidentifikasi faktor-faktor yang mempengaruhinya. Stratified Random Sampling digunakan untuk mengumpulkan data dalam penelitian ini. Total 400 sampel dikumpulkan dan digunakan dalam penelitian ini. Survei berbasis rumah tangga dilakukan untuk menanyakan pertanyaan terkait informasi responden seperti pengeluaran perjalanan, sosial-ekonomi, dan atribut mobilitas mereka. Kuesioner dibagikan pada ke enam kecamatan di Banda Aceh, yaitu Syiah Kuala, Ulee Kareng, Lueng Bata, Meuraxa, Kuta Raja dan Kuta Alam, di mana kecamatan terpilih memiliki kecamatan yang paling padat penduduknya. Modelkan regresi linier menggunakan metode rata-rata kuadrat terkecil untuk mengestimasi parameter regresi model. Model yang dikalibrasi untuk pengeluaran transportasi. Nilai koefisien determinasi yang diperoleh dalam model sebesar 0,965. Temuan empiris mengungkapkan bahwa faktor-faktor yang mempengaruhi pengeluaran transportasi rumah tangga termasuk tujuan perjalanan, waktu perjalanan, total pendapatan rumah tangga, jumlah kepemilikan mobil dan jumlah kepemilikan sepeda motor.
\end{abstract}

Kata kunci: Rumah Tangga, Pengeluaran Transportasi, Ordinary Least Square, Banda Aceh

\begin{abstract}
To date, the city of Banda Aceh has continued to experience rapid development both in transportation infrastructure and increased in population, as a result, this affecting the number of people to travel for their routine activities. By spending more time to traveling has a significant influence on the costs for their routine transportation. Therefore, this study aims to determine a model of the transportation expenditures in Banda Aceh. A developed model could be used to explore the characteristics of travel expenditure by identifying its influencing factors. Stratified random sampling is used for collecting data in this study. In a total of 400 samples were collected and used in this study. Householders home-based survey were conducted to ask respondent's related question such as their travel expenditure, social-economic, and their mobility attributes. The questionnaires were distributed to six subdistricts in Banda Aceh,
\end{abstract}


namely Syiah Kuala, Ulee Kareng, Lueng Bata, Meuraxa, Kuta Raja and Kuta Alam, where the selected sub-districts had the most populated subdistrict. We performed linear regression model using ordinary least square method the regression parameter then estimated. Calibrated model for transportation expenditure, the value coefficient of determination obtained in our model is 0.965 . Our empirical finding reveals that the influencing factors to household transportation expenditure include travel destination, travel time, total household income, number of car ownership and number of motorcycle ownership. Keywords: Household, Transportation Expenditure, Ordinary Least Square, Banda
Aceh

\section{Latar Belakang}

Kota Banda Aceh adalah ibu kota provinsi Aceh dengan luas wilayah 61,36 $\mathrm{km}^{2}$ dan jumlah penduduk sebanyak 259.913 jiwa (Data BPS Tahun 2017) yang terus mengalami perkembangan pesat baik dalam prasarana transportasi, pembangunan infrastruktur serta peningkatan jumlah penduduk, sehingga mempengaruhi banyaknya orang yang melakukan aktivitas perjalanan untuk berbagai tujuan kegiatan. Seiring dengan perkembangan motorisasi, menjanjikan pertumbuhan ekonomi dan akibat pengaruh urbanisasi yang cepat akan membuat gaya hidup masyarakat semakin banyak menghabiskan waktu dalam perjalanan. Menghabiskan lebih banyak waktu untuk bepergian memiliki pengaruh yang signifikan terhadap biaya pengeluaran transportasi rumah tangga. Menurut Sugiarto dkk. (2014) biaya pengeluaran transportasi adalah sebuah fakta di mana dapat didefinisikan sebagai besaran pengeluaran rata-rata dari pendapatan rumah tangga di wilayah tertentu untuk memenuhi kebutuhan rutinitas dengan berbasis perjalanan. Biaya perjalanan erat hubungannya dengan tingkat pendapatan, selain itu lokasi geografis juga menjadi subjek kolaborasi berkelanjutan yang memperkirakan biaya perjalanan dengan menggunakan survei transportasi rumah tangga yang komprehensif. Pada dasarnya penelitian mengenai analisis biaya pengeluaran transportasi rumah tangga masih terlalu sedikit yang melakukan dan kajian mengenai masalah biaya pengeluaran transportasi rumah tangga jauh lebih sedikit dibahas di dalam literatur. Sebenarnya, biaya transportasi berpengaruh signifikan terhadap bagaimana rumah tangga mengeluarkan uang untuk biaya transportasi rutin.

Analisis deskriptif dan regresi linier sering digunakan untuk memverifikasi kestabilan dari biaya pengeluaran transportasi rumah tangga. Penelitian menunjukkan bahwa rata-rata rumah tangga yang memiliki kendaraan menghabiskan sekitar $10-11 \%$ dari pendapatannya dalam biaya perjalanan mereka. Sementara, rata-rata rumah tangga yang tidak memiliki kendaraan menghabiskan sekitar 3-5\% dari pendapatan dalam biaya perjalanan. Biaya pengeluaran transportasi rumah tangga akan meningkat seiring dengan meningkatnya motorisasi. Biaya pengeluaran transportasi yang dikeluarkan dalam suatu rumah tangga akan berbeda nilainya, hal ini berpengaruh berdasarkan jumlah pendapatan dari rumah tangga itu sendiri. Saleh dkk. (2016) dan Sugiarto dkk. (2014) mengungkapkan bahwa pendapatan/penghasilan yang diterima oleh rumah tangga berasal dari pendapatan kepala rumah tangga maupun pendapatan anggota-anggota rumah tangga yang didasarkan terhadap masing-masing pekerjaan atau profesi seseorang dan banyaknya jumlah anggota keluarga yang 
bekerja. Beberapa faktor karakteristik yang mempengaruhi biaya pengeluaran transportasi rumah tangga diantaranya karakteristik sosio-ekonomi rumah tangga dan karakeristik perilaku perjalanan

Berdasarkan latar belakang dalam uraian diatas, maka penelitian ini bertujuan untuk mendapatkan model pengeluaran transportasi rumah tangga di kota Banda Aceh dan mengetahui karakteristik dengan mengidentifikasi faktorfaktor yang mempengaruhi pengeluaran transportasi rumah tangga di kota Banda Aceh. Terdapat 9 (sembilan) kecamatan di kota Banda Aceh, yaitu Syiah Kuala, Kuta Raja, Meuraxa, Ulee Kareng, Lueng Bata, Kuta Raja, Banda Raya, Baiturrahman dan Jaya Baru. Pada kasus penelitian ini hanya diambil 6 (enam) kecamatan yang akan mewakili dari seluruh kecamatan yang mempunyai jumlah penduduk terbesar dari kecamatan lainnya, yaitu Syiah Kuala, Ulee Kareng, Lueng Bata, Meuraxa, Kuta Raja dan Kuta Alam. Lokasi penelitian diperlihatkan pada Gambar 1

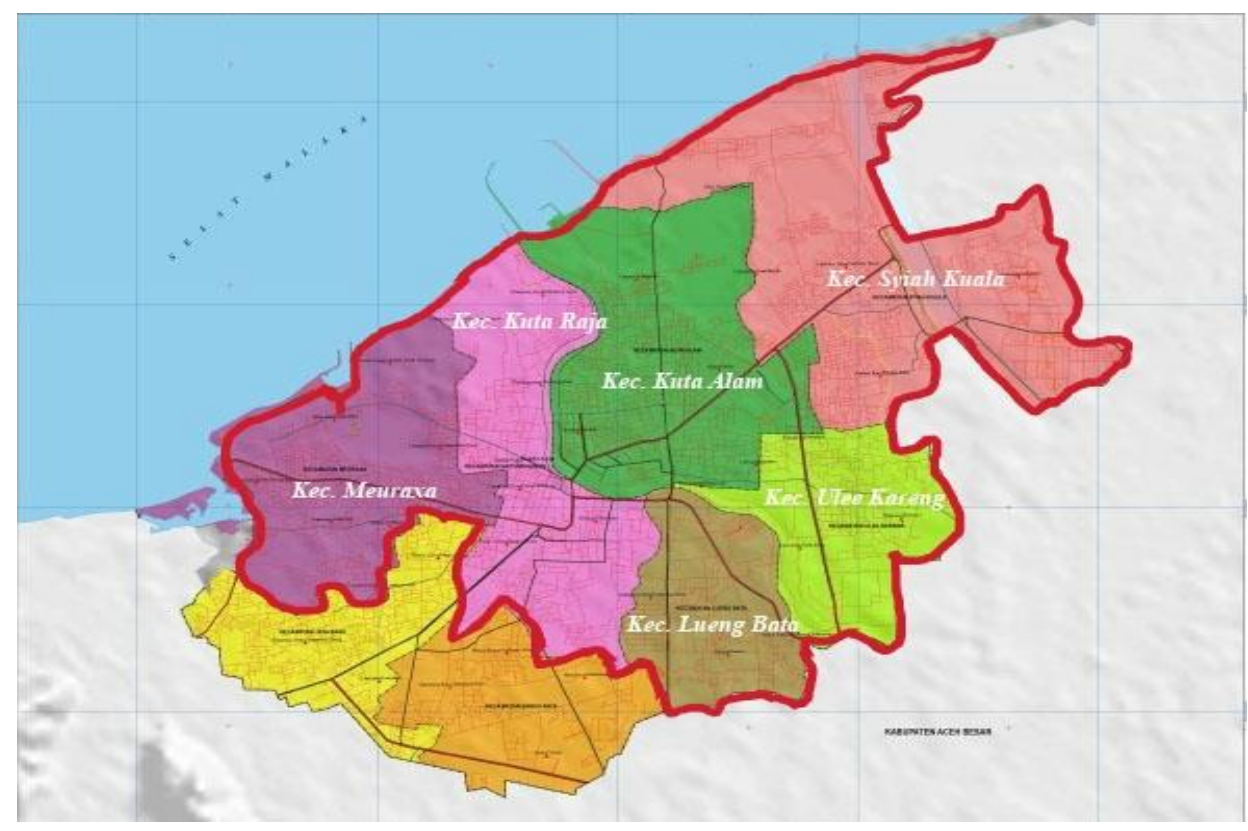

Gambar 1 Peta lokasi penelitian

\section{Metode Penelitian}

Penelitian dimulai dengan rumusan latar belakang dan urgensi penelitian, kemudian dilanjutkan dengan pengumpulan data primer dan sekunder. Setelah semua data terkumpul dilakukan tahapan pengolahan data dan analisis data. Pengolahan data berupa analisis deskriptif terhadap karakteristik sosio-ekonomi rumah tangga dan karakteristik perilaku perjalanan. Analisis data digunakan metode pemodelan analisis regresi linear dengan Metode estimasi parameter digunakan Ordinary Least Square (OLS). Dalam pemodelan ini terdiri dari beberapa tahapan yaitu setting variabel bebas, pengeditan (editing), pengkodean (coding), pemasukan data (entry/processing), pembersihan data (cleaning) dan kalibrasi parameter model. Hasil dan pembahasan dilakukan setelah model akhir terpilih sesuai dengan syarat dan ketentuan dalam pemilihan model berdasarkan nilai Goodness of Fit (GoF) model. 
Ada beberapa indeks dihitung untuk menjelaskan fit dari model dalam proses kalibrasi model, diantaranya adjusted $\mathrm{R}^{2}(\geq 0,70)$, uji $\mathrm{F}(\leq 0,05)$, uji $\mathrm{t}(\leq$ $0,05)$, dan uji asumsi klasik yang meliputi auto korelasi yaitu digunakan Tabel Durbin-Watson $(\mathrm{DW})$ test (error $=0,05)$ yang hasilnya adalah DW hitung, angka ini akan dibandingkan dengan nilai $\mathrm{dL}$ dan dU ditentukan berdasarkan jumlah variabel bebas dalam model regresi (k) dan jumlah sampelnya (n). Selanjutnya heteroskedastisitas yaitu dengan membuat Scatterplot (alur sebaran) antara residual $(\mathrm{Y})$ dan nilai prediksi $(\mathrm{X})$ dari variabel terikat yang telah distandarisasi, jika sebaran titik tidak membentuk suatu pola/alur tertentu, maka disimpulkan tidak terjadi heteroskedastisitas dan model terpenuhi. Multikolinieritas yaitu digunakan nilai variance inflation factor (VIF), jika nilai VIF $(\geq 10)$ maka terjadi multikolinieritas dan jika nilai VIF $(\leq 10)$ maka tidak terjadi multikolinieritas dan terakhir normalitas digunakan gambar Normal P-P Plot untuk melihat sebaran titik-titiknya, apabila sebaran titik-titik data mendekati atau rapat pada garis lurus (diagonal 45 derajat), maka data terdistribusi normal.

\subsection{Populasi dan Sampel}

Menurut Sugiyono (2011:92) teknik sampling adalah teknik pengambilan sampel untuk menentukan sampel yang akan digunakan dalam penelitian, pada penelitian ini digunakan proportionate stratified random sampling, Teknik sampling ini banyak digunakan dalam kajian transportasi seperti penerapan pada kajian penerimaan masyarakat terhadap kebijakan transportasi (Sugiarto dkk. 2017; Merfazi dkk. 2019), kajian tentang bangkitan pergerakan sepeda motor (Anggraini, R dkk. 2017; Balqis dkk. 2018; Hikmi dkk. 2018), kajian tentang tanggapan publik terhadap kebijakan perubahan ke moda bus (Saleh, S.M. dkk. 2019) dan kajian tentang pemodelan pemilihan moda dengan menggunakan metode SP juga dilakukan oleh Isya dkk, (2013) dengan fokus kajian adalah pemilihan moda antara BRT dan sepeda motor menuju ke kampus Unsyiah, Darussalam. Jumlah sampel yang digunakan pada penelitian ini adalah sebanyak $400 \mathrm{KK}$ dari populasi penelitian berjumlah $42.751 \mathrm{KK}$ yang diperoleh dari jumlah masing-masing desa di 6 (enam) kecamatan yang menjadi lokasi penelitian di Kota Banda Aceh. Penentuan jumlah sampel menggunakan rumus Slovin dengan tingkat kesalahan (e) diasumsikan 5\%, maka diperoleh jumlah sampel:

$$
\begin{aligned}
& n=\frac{N}{1+\left(N x e^{2}\right)} \\
& n=\frac{42.751}{1+\left(42.751 \times 0,05^{2}\right)}=399,9 \approx 400
\end{aligned}
$$

dimana $\mathrm{N}$ adalah jumlah populasi; $\mathrm{n}$ adalah jumlah sampel dan e adalah batas toleransi kesalahan (digunakan 5\%).

\subsection{Pengumpulan Data}

Objek penelitian adalah suatu rumah tangga yang melakukan aktivitas perjalanan dengan menggunakan moda transportasi dalam tujuan kegiatannya, baik dengan moda transportasi pribadi maupun umum sehingga timbulnya biaya pengeluaran transportasi rumah tangga pada beberapa kecamatan yang menjadi 
lokasi penelitian serta faktor-faktor yang berpengaruh terhadap biaya pengeluaran transportasi rumah tangga tersebut. Pada penelitian ini yang menjadi responden dalam memperoleh data informasi rumah tangga hanya ditujukan kepada kepala keluarga saja dan juga sebagai yang mewakili dalam memperoleh informasi dari setiap anggota keluarga yang melakukan aktivitas perjalanan.

Pengumpulan data dilakukan dengan wawancara langsung kepada kepala keluarga dan dicatat oleh surveyor ke dalam formulir kuisioner yang sudah disiapkan. Kuesioner dalam penelitian ini merupakan daftar pertanyaan terstruktur yang dirancang untuk mengetahui kenyataan-kenyataan yang ada pada suatu rumah tangga. Kuesioner dibuat dengan sedemikian rupa sehingga mempermudah pewawancara (interviewer) dalam melakukan wawancara kepada kepala keluarga untuk mengisi daftar pertanyaan yang ada di dalam kuesioner tersebut. Pertanyaan yang diberikan meliputi karakteristik sosio-ekonomi rumah tangga dan karakteristik perilaku perjalanan (travel behavior).

Pelaksanaan survei dengan membagikan kuesioner kepada rumah tangga di setiap desa pada kecamatan yang diteliti untuk diisi langsung oleh responden dengan didampingi oleh pewawancara (interviewer). Kuesioner yang dibagikan akan diambil pada hari yang sama atau hari yang lain jika responden belum selesai mengisi semua pertanyaan yang ada. Kegiatan studi ini dilakukan pada hari kerja yaitu pada hari Senin - Jum'at dari pagi hingga sore selama jam kerja. Pembagian kuesioner dilakukan selama satu bulan yang dimulai pada pukul 08.00-18.00 WIB.

\subsection{Pengolahan Data dan Analisis}

Pengolahan data yang dilakukan adalah analisis deskriptif dengan menggunakan regresi linier dan kalibrasi parameter digunakan Metode OLS menggunakan software SPSS. Model persamaan regresi linier secara umum:

$$
Y=a+b_{1} X_{1}+b_{2} X_{2}+b_{3} X_{3} \ldots \ldots+b_{n} X_{n}
$$

di mana $\mathrm{Y}$ adalah pengeluaran transportasi; $\mathrm{a}, \mathrm{b}_{1}, \mathrm{~b}_{2} \ldots$ bn adalah skala parameter resgresi yang harus diestimasi dan $\mathrm{X}_{1}, \mathrm{X}_{2}, \mathrm{X}_{3} \ldots \mathrm{Xn}$ merupakan variabel penjelas/regressor yang dipilih.

Untuk melakukan analisis dengan pemodelan regresi linier berganda digunakan dua kategori variabel yaitu variabel terikat (Y) dan bebas (X), variabel terikat pada penelitian ini yaitu Y (Pengeluaran Transportasi Rumah Tangga) dan variabel bebas $(\mathrm{X})$ terdiri dari 15 variabel yaitu $\mathrm{X}_{1}$ (Jenis moda transportasi yang digunakan); $\mathrm{X}_{2}$ (Tujuan Perjalanan); $\mathrm{X}_{3}$ (Jarak Tempuh Perjalanan); $\mathrm{X}_{4}$ (Waktu Tempuh Perjalanan); $\mathrm{X}_{5}$ (Frekuensi Perjalanan); $\mathrm{X}_{6}$ (Total Penghasilan/Pendapatan Rumah Tangga); $\mathrm{X}_{7}$ (Jenis Kelamin); $\mathrm{X}_{8}$ (Usia); $\mathrm{X}_{9}$ ( Tingkat Pendidikan Terakhir); $\mathrm{X}_{10}$ (Jenis Pekerjaan); $\mathrm{X}_{11}$ (Status Kepemilikan Rumah); $\mathrm{X}_{12}$ (Jumlah Anggota Keluarga); $\mathrm{X}_{13}$ (Jumlah Anggota Keluarga yang Sudah Bekerja); $\mathrm{X}_{14}$ (Jumlah Kepemilikan Mobil) dan $\mathrm{X}_{15}$ (Jumlah Kepemilikan Sepeda Motor). Dalam mengestimasi dengan menggunakan pemodelan regresi linier berganda, beberapa tahapan proses yang perlu dilakukan adalah analisis bivariat yang merupakan uji korelasi untuk melihat hubungan antar variabel yaitu variabel terikat dengan variabel bebas. Pada langkah awal dengan memilih variabel bebas 
yang mempunyai korelasi yang besar dengan variabel terikatnya, langkah berikutnya menyeleksi variabel bebas yang saling berkorelasi, jika ada antara variabel bebas memiliki korelasi besar maka untuk ini dipilih salah satu, dengan kata lain korelasi harus kecil antara sesama variabel bebas dan pada tahap akhir dengan memasukkan variabel bebas dan variabel terikat kedalam pemodelan regresi linear berganda secara matematis terurai pada persamaan (2) diatas. Estimasi parameter digunakan program SPSS dengan menggunakan metode pendekatan Ordinary Least Square (Pramanda. 2017).

\section{Hasil dan Pembahasan}

\subsection{Ekonomi Rumah Tangga dan Perilaku Perjalanan}

Distribusi dari karakteristik sosio-ekonomi rumah tangga dan perilaku perjalanan responden seperti diperlihatkan pada Tabel 1, menggambarkan bahwa variabel jenis kelamin jumlah responden yang berjenis kelamin laki-laki lebih mendominasi sebanyak $82,7 \%$ dibandingkan dengan jumlah responden perempuan, hal ini karena dalam penelitian ini yang menjadi responden dalam survey rumah tangga hanya ditujukan kepada kepala keluarga saja dan bukan setiap anggota keluarga, sehingga responden laki-laki jauh lebih mendominasi dibandingkan dengan jumlah responden perempuan. Untuk usia didominasi oleh responden dengan rentang usia antara 40-49 tahun sebanyak 54,5\% dan sebagian besar bekerja sebagai PNS yang berkontribusi sebanyak 48,3\%. Distribusi perilaku perjalanan menunjukkan bahwa tujuan perjalanan yang paling dominan dilakukan adalah untuk kegiatan bekerja/dinas sebanyak $64,3 \%$ dari total responden. Untuk waktu tempuh perjalanan yang dilakukan dalam aktivitas sehari-hari didominasi dengan rentang antara 10-20 Menit yaitu sebesar 52,7\%. Untuk jenis moda transportasi yang paling sering digunakan dalam aktivitas sehari-hari, sebanyak $77,5 \%$ dari responden memilih menggunakan moda transportasi pribadi.

Tabel 1 Distribusi karakteristik responden dan perilaku perjalanan

\begin{tabular}{llrllr}
\hline \multicolumn{1}{c}{ Item } & \multicolumn{1}{c}{ Kategori } & $\mathbf{( \% )}$ & \multicolumn{1}{c}{ Item } & \multicolumn{1}{c}{ Kategori } & $(\boldsymbol{\%})$ \\
\hline Jenis & Laki-laki & $82,7 \%$ & Pendapatan & $\leq 3$ Juta & $16,5 \%$ \\
Kelamin & Perempuan & $17,3 \%$ & Bulanan & 3-5 Juta & $65,5 \%$ \\
& & & RT (Rp) & $\geq 5$ juta & $18,0 \%$ \\
\hline Usia & $\leq 20-29$ & $12,7 \%$ & Waktu & $5-10$ menit & $34,3 \%$ \\
(tahun) & $30-39$ & $29,5 \%$ & Tempuh & $10-20$ menit & $52,7 \%$ \\
& $40-49$ & $54,5 \%$ & Perjalanan & 20-30 menit & $10,3 \%$ \\
& $\geq 50$ & $3,3 \%$ & & $\geq 30$ menit & $2,7 \%$ \\
\hline Pend. & $\leq$ SMA & $54,7 \%$ & Tujuan & Bekerja/dinas & $64,3 \%$ \\
Terakhir & Diploma & $13,3 \%$ & Perjalanan & Sekolah/kuliah & $9,0 \%$ \\
& Sarjana & $22,7 \%$ & & Bisnis/usaha & $26,7 \%$ \\
& Magister/Doktor & $9,3 \%$ & & & \\
& & & & & \\
\hline Jenis & PNS & $48,3 \%$ & Jenis Moda & Sepeda Motor & $51,7 \%$ \\
Pekerja- & Pegawai Swasta & $17,2 \%$ & Transportasi & Mobil Pribadi & $25,8 \%$ \\
an & Pengusaha/wiraswasta & $27,0 \%$ & yang & Bus & $9,0 \%$ \\
& Pelajar/mahasiswa & $7,5 \%$ & digunakan & Labi-labi & $1,0 \%$
\end{tabular}

Analisis Pengeluaran Transportasi Rumah Tangga (Transportation Expenditure) di 


\begin{tabular}{lr} 
Becak & $2,0 \%$ \\
Transport & $10,5 \%$ \\
Online & \\
\hline
\end{tabular}

\subsection{Hasil Uji Korelasi}

Variabel yang digunakan dalam menentukan model regresi harus diseleksi dengan uji korelasi (r) antar semua variabel yang ditinjau dan akan menghasilkan koefisien korelasi antara variabel terikat $(\mathrm{Y})$ dan variabel bebas $(\mathrm{X})$ dan koefisien korelasi antar variabel bebas (X). Apabila terdapat korelasi kuat sesama variabel bebas, maka antara variabel bebas tersebut dipilih salah satu yang mempunyai nilai korelasi yang terbesar untuk mewakili.

Tabel 2 Matriks hasil uji korelasi

\begin{tabular}{|c|c|c|c|c|c|c|c|c|c|c|c|c|c|c|c|c|}
\hline & $\bar{Y}$ & $\mathrm{X}_{1}$ & $\mathrm{X}_{2}$ & $\mathrm{X}_{3}$ & $\mathrm{X}_{4}$ & $\mathrm{X}_{5}$ & $\mathrm{X}_{6}$ & $\mathrm{X}_{7}$ & $\mathrm{X}_{8}$ & $\mathrm{X}_{9}$ & $\mathrm{X}_{10}$ & $X_{11}$ & $\mathrm{X}_{12}$ & $\mathrm{X}_{13}$ & $\mathrm{X}_{14}$ & $\mathrm{X}_{15}$ \\
\hline $\mathrm{Y}$ & 1 & & & & & & & & & & & & & & & \\
\hline $\mathrm{X}_{1}$ & $.435^{* *}$ & 1 & & & & & & & & & & & & & & \\
\hline $\mathrm{X}_{2}$ & $.406^{\text {w*t }}$ & $.468^{* *+4}$ & 1 & & & & & & & & & & & & & \\
\hline $\mathrm{X}_{3}$ & $460^{* * *+1}$ & .057 & -.034 & 1 & & & & & & & & & & & & \\
\hline $\mathrm{X}_{4}$ & $477^{\text {s** }}$ & .066 & .017 & $947^{4+4}$ & 1 & & & & & & & & & & & \\
\hline$X_{5}$ & $.319^{* * *}$ & $.134^{* * *}$ & $.547^{* * t}$ & .073 & $.151^{\text {w*th }}$ & 1 & & & & & & & & & & \\
\hline$X_{6}$ & $527^{\text {thn }}$ & $.239^{\circ * 4}$ & $185^{\text {twt }}$ & $.339^{* * t}$ & $.359^{* * 4}$ & $.271^{\text {"N }}$ & 1 & & & & & & & & & \\
\hline$X_{7}$ & $.186^{* * *}$ & $313^{* * 4}$ & $.348^{* *}$ & $219^{* * *}$ & $.218^{* * *}$ & $282^{n+4}$ & .039 & 1 & & & & & & & & \\
\hline $\mathrm{X}_{8}$ & $362^{*+4}$ & $240^{*+*}$ & $.228^{*+*}$ & .053 & .059 & -.058 & $.167^{*+*}$ & $-.158^{\prime \prime}$ & 1 & & & & & & & \\
\hline $\mathrm{X}_{9}$ & $-247^{*+1}$ & $-.152^{*+1}$ & -.156 & .005 & .051 & .034 & $106^{*}$ & $.150^{* \prime}$ & $-.298^{* 4}$ & 1 & & & & & & \\
\hline$X_{10}$ & $.473^{\text {*+⿱ }}$ & $389^{+4+4}$ & $.543^{*+*}$ & $201^{*+4}$ & $255^{*+1 / 2}$ & $370^{*+4}$ & $.410^{*+*}$ & $328^{+1+4}$ & $261^{*+4}$ & -.008 & 1 & & & & & \\
\hline$X_{11}$ & $.544^{* *}$ & $381^{1+1}$ & $390^{* * 7}$ & $237^{*+1}$ & $263^{*+4}$ & $266^{\prime \prime \prime}$ & $.382^{*+17}$ & $204^{\text {p+7 }}$ & $320^{* *+}$ & .062 & $431^{* 7}$ & 1 & & & & \\
\hline$X_{12}$ & $.603^{\text {t+4 }}$ & $.441^{14}$ & $.433^{n+*}$ & $209^{*+4}$ & $.221^{*+14}$ & $.176^{n+4}$ & $.343^{\text {st+ }}$ & $192^{\prime \prime+1}$ & $.521^{*+4}$ & $.251^{\prime \prime}$ & $.434^{4+14}$ & $.563^{*+1}$ & 1 & & & \\
\hline$X_{13}$ & $.643^{n+4}$ & $.242^{\prime \prime \prime}$ & $.233^{n+1+}$ & $.226^{* 4+}$ & $.243^{n+4}$ & $.155^{\text {D* }}$ & $.482^{m+n}$ & .071 & $.405^{*+\pi}$ & $=.139^{\prime \prime}$ & $.324^{414}$ & $.398^{* 4+}$ & $663^{*+1}$ & 1 & & \\
\hline$X_{14}$ & $.743^{\text {"wt" }}$ & $.343^{\prime \prime \prime}$ & $.260^{m * n}$ & $.371^{m+1}$ & $.363^{*+1 *}$ & $169^{m+m}$ & $306^{n+m}$ & $.258^{* 17}$ & $.328^{n+n}$ & $=.368^{\prime \prime}$ & $.325^{\circ 17}$ & $.466^{* 1+1}$ & $478^{* 1+1}$ & $.463^{\mathrm{mt}}$ & 1 & \\
\hline$X_{15}$ & $.698^{\text {"*t }}$ & $.371^{\prime \prime \prime}$ & $.183^{*+*}$ & $.323^{m * *}$ & $.335^{* *+4}$ & $.154^{\prime \prime \prime}$ & $.533^{\text {tw* }}$ & .029 & $.339^{* * *}$ & $-.167^{\prime \prime}$ & $.276^{\prime 2 *}$ & $.408^{\text {"wt }}$ & $571^{*+1}$ & $.644^{\prime \prime *}$ & $.428^{\prime \prime \prime}$ & 1 \\
\hline
\end{tabular}

Dari Tabel 2, memperlihatkan bahwa terdapat 11 (sebelas) variabel bebas yang memiliki korelasi yang tinggi dibandingkan dengan variabel-variabel lainnya. Sehingga kesebelas variabel tersebut yang akan dipakai untuk mendapatkan model yang terbaik. Variabel jenis moda $\left(\mathrm{X}_{1}\right)$ mempunyai hubungan yang signifikan dengan biaya pengeluaran transportasi rumah tangga $(\mathrm{Y})$ dengan nilai $\mathrm{R}$ (koefisien korelasi) yaitu sebesar 0,435 atau variabel bebas dapat mempengaruhi variabel terikat dengan kuat hubungan sebesar 43,5\%, dan pada tujuan perjalanan $\left(\mathrm{X}_{2}\right)$ mempunyai hubungan yang signifikan dengan biaya pengeluaran transportasi rumah tangga (Y) dengan nilai $\mathrm{R}$ (koefisien korelasi) yaitu sebesar 0,406 atau variabel bebas dapat mempengaruhi variabel terikat dengan kuat hubungan sebesar 40,6\%. Selanjutnya pada variabel jarak tempuh $\left(\mathrm{X}_{3}\right)$ mempunyai hubungan yang signifikan dengan biaya pengeluaran transportasi rumah tangga (Y) dengan nilai $\mathrm{R}$ (koefisien korelasi) yaitu sebesar 0,460 atau variabel bebas dapat mempengaruhi variabel terikat dengan kuat hubungan 
sebesar $46 \%$, waktu tempuh $\left(\mathrm{X}_{4}\right)$ mempunyai hubungan yang signifikan dengan pengeluaran transportasi rumah tangga (Y) dengan nilai R (koefisien korelasi) yaitu sebesar 0,477 atau variabel bebas dapat mempengaruhi variabel terikat dengan kuat hubungan sebesar $47,7 \%$, variabel jumlah pendapatan rumah tangga $\left(\mathrm{X}_{6}\right)$ mempunyai hubungan yang signifikan dengan biaya pengeluaran transportasi rumah tangga $(\mathrm{Y})$ dengan nilai $\mathrm{R}$ (koefisien korelasi) yaitu sebesar 0,527 atau variabel bebas dapat mempengaruhi variabel terikat dengan kuat hubungan sebesar 52,7\%, jenis pekerjaan $\left(\mathrm{X}_{10}\right)$ mempunyai hubungan yang signifikan dengan biaya pengeluaran transportasi rumah tangga (Y) dengan nilai R (koefisien korelasi) yaitu sebesar 0,473 atau variabel bebas dapat mempengaruhi variabel terikat dengan kuat hubungan sebesar 47,3\%, selanjutnya variabel status kepemilikan rumah $\left(\mathrm{X}_{11}\right)$ mempunyai hubungan yang signifikan dengan biaya pengeluaran transportasi rumah tangga $(\mathrm{Y})$ dengan nilai $\mathrm{R}$ (koefisien korelasi) yaitu sebesar 0,544 atau variabel bebas dapat mempengaruhi variabel terikat dengan kuat hubungan sebesar $54,4 \%$, jumlah anggota keluarga $\left(\mathrm{X}_{12}\right)$, jumlah anggota keluarga yang bekerja $\left(\mathrm{X}_{13}\right)$, jumlah kepemilikan mobil $\left(\mathrm{X}_{14}\right)$ dan jumlah kepemilikan sepeda motor $\left(\mathrm{X}_{15}\right)$ mempunyai hubungan yang signifikan dengan biaya pengeluaran transportasi rumah tangga (Y) dengan nilai $\mathrm{R}$ (koefisien korelasi) masing-masing yaitu sebesar 0,$603 ; 0,643 ; 0,743$ dan 0,698 atau variabel bebas dapat mempengaruhi variabel terikat dengan kuat hubungan sebesar 60,3\%; $64,3 \% ; 74,3 \%$ dan $69,8 \%$.

\subsection{Hasil Kalibrasi Parameter Model Regresi}

Pengujian regresi dilakukan untuk meramalkan suatu variabel terikat (Y) berdasarkan dua atau lebih variabel bebas (X) dalam suatu persamaan linear. Untuk mendapatkan model yang paling sesuai menggambarkan pengaruh satu atau beberapa variabel bebas terhadap variabel terikatnya dapat digunakan analisis regresi linear berganda (multiple linear regression analysis). Pengujian regresi linear berganda dilakukan dengan menggunakan variabel-variabel bebas yang mempunyai korelasi kuat terhadap jumlah bangkitan pergerakan (Y). Selanjutnya masing-masing variabel bebas tersebut dimasukkan ke dalam persamaan regresi dengan kombinasi beberapa variabel bebasnya secara coba-coba.

Tabel 3 Hasil kalibrasi parameter model regresi

\begin{tabular}{|c|c|c|c|c|c|}
\hline Model Regesi & $\begin{array}{c}\text { Koefi } \\
\text { sien } \\
\text { Regresi } \\
\end{array}$ & $\mathbf{t}$ & sig. & $\begin{array}{c}\text { Toleran } \\
\text { ce }\end{array}$ & VIF \\
\hline Tujuan perjalanan $\left(X_{2}\right)$ & 0,278 & 11,136 & 0,000 & 0,285 & 3,513 \\
\hline Waktu tempuh $\left(\mathrm{X}_{4}\right)$ & 0,017 & 7,766 & 0,000 & 0,207 & 4,830 \\
\hline Total pendapatan RT $\left(\mathrm{X}_{6}\right)$ & 0,168 & 4,690 & 0,000 & 0,125 & 7,971 \\
\hline Kepemilikan mobil $\left(\mathrm{X}_{14}\right)$ & 0,334 & 16,109 & 0,000 & 0,556 & 1,797 \\
\hline Kepemilikan sepeda motor $\left(\mathrm{X}_{15}\right)$ & 0,266 & 14,744 & 0,000 & 0,121 & 8,269 \\
\hline
\end{tabular}

Kesesuaian model regresi yang terbentuk: $F=2167,689$ dan Sig. 0,000

Koefisien korelasi $(\mathrm{R})=0,982$

Koefisien determinasi $(\mathrm{R}$ square $)=0,965$

Persamaan regresi: $Y=0,278 X_{2}+0,017 X_{4}+0,168 X_{6}+0,334 X_{14}+0,266 X_{15}$ 
Berdasarkan Tabel 3 memperlihatkan bahwa hasil kalibrasi parameter model dari beberapa persamaan (model) regresi linier berganda didapatkan model yang terbaik yaitu $Y=0,278 X_{2}+0,017 X_{4}+0,168 X_{6}+0,334 X_{14}+0,266 X_{15}$. Karena model tersebut memenuhi persyaratan, selanjutnya dilakukan pengujian residual.

\subsection{Hasil Pengujian Residual}

Uji residual merupakan pengujian asumsi klasik di mana tidak dilakukan operasionalisasi software SPSS, melainkan hanya membaca asumsi klasik dari output SPSS.

Tabel 4 Hasil pengujian residual

\begin{tabular}{ccll}
\hline No. & Pengujian & \multicolumn{1}{c}{ Percobaan } & Hasil \\
\hline 1 & Uji Autokorelasi & Nilai Dw hitung $=2,072$ & \\
& & Nilai dU $=1,856$ & \\
& & Nilai 4-dU $=2,144$ & Tidak terjadi \\
& & Sehingga Nilai Dw hitung $>$ & Autokorelasi \\
& & nilai dU dan Nilai Dw & \\
& & hitung $<$ nilai 4-dU & \\
\hline 2 & Uji Multikolinieritas & Nilai VIF & \\
& & $*\left(\mathrm{X}_{2}\right)=3,513$ & \\
& & $*\left(\mathrm{X}_{4}\right)=4,830$ & Tidak terjadi \\
& & $*\left(\mathrm{X}_{6}\right)=7,971$ & Multikolinieri \\
& & $*\left(\mathrm{X}_{14}\right)=1,797$ & tas \\
& & $*\left(\mathrm{X}_{15}\right)=8,269$ & \\
& & Sehingga nilai VIF dari & \\
& & kelima variabel tidak ada & \\
& & yang lebih besar dari 10 & \\
\hline 3 & Uji Heteroskedastisitas & Dari gambar Scatterplot & \\
& & terlihat bahwa sebaran titik- & Homoskedasti \\
& & titik tidak membentuk suatu & sitas \\
& & pola/alur tertentu & \\
\hline 4 & & Dari gambar Normal P-P & \\
& & Plot terlihat bahwa sebaran & Terdistribusi \\
& & titik-titik relatif mendekati & normal \\
& & garis lurus & \\
\hline & & &
\end{tabular}

Dari Tabel 4 memperlihatkan bahwa persamaan (model) regresi linier berganda yang terbentuk merupakan model regresi yang sesuai dengan persyaratan lulus uji residual.

\subsection{Hasil Pemodelan Regresi Linier Berganda}

Persamaan (model) regresi linier berganda yang terbentuk untuk pengeluaran transportasi rumah tangga di Kota Banda Aceh yaitu:

$$
Y=0,278 X_{2}+0,017 X_{4}+0,168 X_{6}+0,334 X_{14}+0,266 X_{15}
$$


merupakan model regresi yang sesuai menggambarkan pengaruh 5 (lima) variabel bebas, yaitu tujuan perjalanan $\left(\mathrm{X}_{2}\right)$, waktu tempuh $\left(\mathrm{X}_{4}\right)$, total pendapatan rumah tangga $\left(\mathrm{X}_{6}\right)$, jumlah kepemilikan mobil $\left(\mathrm{X}_{14}\right)$, dan jumlah kepemilikan sepeda motor $\left(\mathrm{X}_{15}\right)$ yang secara bersamaan mempengaruhi biaya pengeluaran transportasi rumah tangga $(\mathrm{Y})$, hal ini dapat dilihat dari nilai analisis Anova regresi $(\mathrm{F})$ yang signifikan sebesar 2167,689. Kuat hubungan yang ditunjukkan oleh variabel bebas terhadap variabel terikat dalam model yang terbentuk dapat dilihat pada koefisien determinasi (R square), yaitu sebesar 0,965 atau 96,5\%. Nilai pada variabel tujuan perjalanan $\left(\mathrm{X}_{2}\right)$ yaitu sebesar $0,278 \mathrm{X}_{2}$, dapat diartikan bahwa peningkatan tujuan perjalanan $\left(\mathrm{X}_{2}\right)$ cenderung akan mempengaruhi biaya pengeluaran transportasi rumah tangga. Nilai pada variabel waktu tempuh $\left(\mathrm{X}_{4}\right)$ yaitu sebesar $0,017 \mathrm{X}_{4}$, dapat diartikan bahwa apabila terjadi peningkatan waktu tempuh perjalanan 1 jam akan mempengaruhi biaya pengeluaran transportasi rumah tangga sebesar 0,017 rupiah/juta rupiah. Nilai pada variabel total pendapatan rumah tangga $\left(\mathrm{X}_{6}\right)$ yaitu sebesar $0,168 \mathrm{X}_{6}$, dapat diartikan bahwa peningkatan total pendapatan rumah tangga $\left(\mathrm{X}_{6}\right)$ cenderung akan mempengaruhi biaya pengeluaran transportasi rumah tangga. Nilai pada variabel jumlah kepemilikan mobil $\left(\mathrm{X}_{14}\right)$ yaitu sebesar 0,334 $\mathrm{X}_{14}$, dapat diartikan bahwa apabila terjadi peningkatan jumlah kepemilikan mobil $\left(\mathrm{X}_{14}\right)$ dalam rumah tangga 1 unit akan mempengaruhi biaya pengeluaran transportasi rumah tangga sebesar 0,334 rupiah/juta rupiah dan Nilai pada variabel jumlah kepemilikan sepeda motor $\left(\mathrm{X}_{15}\right)$ yaitu sebesar $0,266 \mathrm{X}_{15}$, dapat diartikan bahwa apabila terjadi peningkatan jumlah kepemilikan sepeda motor $\left(\mathrm{X}_{15}\right)$ dalam rumah tangga 1 unit akan mempengaruhi biaya pengeluaran transportasi rumah tangga sebesar 0,266 rupiah/juta rupiah.

\section{Kesimpulan dan Saran}

\subsection{Kesimpulan}

Berdasarkan hasil analisis yang dilakukan maka dapat diambil beberapa kesimpulan sebagai berikut:

1. Model terbaik untuk pengeluaran transportasi rumah tangga di kota Banda Aceh $Y=0,278 X_{2}+0,017 X_{4}+0,168 X_{6}+0,334 X_{14}+0,266 X_{15}$ dengan nilai koefisien determinasi $\left(\mathrm{R}^{2}\right)$ sebesar 0,965 atau $96,5 \%$.

2. Faktor-faktor yang mempengaruhi pengeluaran transportasi rumah tangga di Kota Banda Aceh yaitu: tujuan perjalanan $\left(\mathrm{X}_{2}\right)$, waktu tempuh $\left(\mathrm{X}_{4}\right)$, total pendapatan rumah tangga $\left(\mathrm{X}_{6}\right)$, jumlah kepemilikan mobil $\left(\mathrm{X}_{14}\right)$, dan jumlah kepemilikan sepeda motor $\left(\mathrm{X}_{15}\right)$.

\subsection{Saran}

Berdasarkan hasil dari penelitian ini, ada beberapa hal yang disarankan untuk menjadi referensi bagi peneliti selanjutnya yaitu:

1. Menggunakan metode pemodelan yang lain seperti dengan Stochastic Frontier Models (SFM).

2. Menggunakan tingkat kesalahan (error tolerance) yang lebih kecil lagi yaitu $1 \%$ dalam penentuan jumlah sampel.

3. Melakukan analisis perbandingan dengan pemodelan biaya pengeluaran transportasi rumah tangga pada cakupan wilayah studi yang lain. 


\section{Daftar Kepustakaan}

Aggraini, R., Sugiarto, S., Pramanda, H, 2017, Factors Affecting Trip Generation of Motorcyclist for the Purpose of Non-Mandatory Activities, AIP Conf. Proc, vol. 1903, 060011.

Balqis, P., Anggraini, R., Sugiarto, S, 2018, Model Bangkitan Pergerakan Pekerja Berdasarkan Tingkat Pendapatan Rumah Tangga (Studi Kasus Kota Banda Aceh), Jurnal Arsip Rekayasa Sipil dan Perencanaan, 1(2), pp. 10-18.

BPS, 2017, Statistik Kota Banda Aceh Tahun 2017, Badan Perencanaan Pembangunan Daerah Kota Banda Aceh, Banda Aceh.

Hikmi, A., Anggraini, R., Sugiarto, S, 2018, Model Bangkitan Pergerakan Penduduk di Kabupaten Aceh Barat Daya Berdasarkan Struktur Rumah Tangga dan Pendapatan Keluarga, Jurnal Arsip Rekayasa Sipil dan Perencanaan, 1(1), pp. 1-9.

Isya, M., Anggraini, R., Sriana, T, 2013, Pemodelan Pemilihan Moda Antara Bus Rapid Transit dan Sepeda Motor dalam Perjalanan Menuju ke Kampus dengan Teknik Stated Preference, Jurnal Teknik Sipil dan Perencanaan, 2(1), pp. 225-236.

Merfazi, M., Sugiarto, S., Anggraini, R, 2019, Persepsi Masyarakat Terhadap Kebijakan Trans Koetaradja Pada Koridor Pusat Kota-Mata Ie dan Pusat Kota-Ajun-Lhoknga Menggunakan Indikator Variabel Laten, Jurnal Arsip Rekayasa Sipil dan Perencanaan, 2(1), pp. 58-67.

Pramanda, H, 2017, Bangkitan Pergerakan Pengguna Sepeda Motor Berdasarkan Tujuan Pergerakan di Kota Lhokseumawe, Tesis Program Magister Teknik Sipil Unsyiah, Banda Aceh.

Saleh, S.M., Sugiarto. S., Anggraini, R, 2019, Analysis on Public's Response Toward Bus Reform Policy in Indonesia Considering Latent Variables, The Open Transportation Journal, 13, 17-24, 18744478.

Saleh, S.M, Sugiarto, 2016, Stochastic Production Frontier Models to Explore Constraints on Household Travel Expenditures Considering Household Income Classes, Aceh International Journal of Science and Technology, 5(1), pp. 9-17.

Sugiarto, Miwa, T, Sato, H, Morikawa, T, 2014, Transportation Expenditure Frontier Models in Jakarta Metropolitan Area, Procedia-Social and Behavioral Sciences, vol. 138, pp. 148-158.

Sugiarto, S., Miwa, T., Sato, H., Morikawa, T, 2017, Explaining Differences in Acceptance Determinants Towards Congestion Charging Policies in Indonesia and Japan, Journal of Urban Planning and Development (ASCE), 143(2), pp. 1-12.

Sugiyono, 2011, Metode Penelitian Kuantitatif, Kualitatif dan R\&D, Alfabeta, Bandung. 